\title{
1. Self-determination: historical underpinnings
}

This chapter will provide a brief introduction to the notion of selfdetermination. Which minority groups are entitled to self-determine their fate, under which circumstances, and toward which goals? The chapter will first discuss the definition of the term "people," as the right to self-determination purposely excludes all minority groups and only extends to those that qualify as "peoples." Next, it will describe the evolution of self-determination, from the colonial era and the idea that colonized peoples ought to be able to govern themselves freely, toward the modern-day noncolonial application of self-determination, whereby oppressed groups are deemed to have the right to govern themselves free of the abusive reign of their mother state. Finally, this chapter will distinguish between the ideas of internal and external self-determination, and it will describe the different forms of self-determination existing around the globe, which include provincial, cultural, social, and/or political autonomy; free association; trusteeships; protectorates; and so on.

\section{"PEOPLE" DEFINED}

Many in the international community agree that defining the term "people" for the purposes of self-determination is a difficult task. ${ }^{1}$ No international treaty has ever defined the term, although most in the international community agree that "people" as linked to the idea of self-determination connotes that a group with a common identity and a link to a specific territory should be entitled to decide its political fate in a democratic fashion.

1 See, e.g., Joshua Castellino, International Law and Self-Determination: Peoples, Indigenous Peoples, and Minorities, in Self-Determination and Secession in International Law (Christian Walter, Antje von Ungern-Sternberg, and Kavus Abushov eds), Oxford: Oxford University Press, 2014, at 32 [hereinafter Walter et al.]. 
Scholars have elaborated that the criteria for peoplehood involve a subjective and an objective element. The subjective element consists of a commonly held belief, by all members of a group, that they constitute a unit and that they share a common history, language, culture, heritage, and political aspirations. The objective elements examine whether members of a particular group share commonalities, such as those mentioned previously (language, culture, ethnicity, political will). Another objective element that scholars have looked at is whether a group has a claim to a particular delineated territory. ${ }^{2}$

Moreover, most agree that peoples are different from minorities-the right to self-determination attaches to the former but not the latter. Minorities have been defined as follows:

a group numerically inferior to the rest of the population of a State, in a non-dominant position, whose members-being nationals of the Statepossess ethnic, religious or linguistic characteristics differing from those of the rest of the population and show, if only implicitly, a sense of solidarity, directed towards preserving their culture, religion or language. ${ }^{3}$

One of the main distinctions between minorities and peoples lies in the notion that minorities live within a larger mother state with a representative government and thus do not need to exercise political autonomy vis-à-vis their mother state. Minority rights are thus focused on the preservation of the minority group's culture and identity, and not necessarily on the group's political rights, as those are deemed to be well respected by the mother states.

Minority rights are protected by several international law instruments, within a larger premise that minority groups are adequately and effectively represented by the government of the larger mother state. "Minority rights protect the existence of national, religious, linguistic or ethnic groups, facilitate the development of their identity and ensure that they can fully and effectively participate in all aspects of public life within the state." 4 Article 27 of the International Covenant on Civil and Political Rights (ICCPR) provides that "[i]n those States in which ethnic, religious or linguistic minorities exist, persons belonging to such minorities shall

2 See, e.g., Michael P. Scharf, Earned Sovereignty: Judicial Underpinnings, 31 Denver Journal of International Law and Policy 373-9 (2003).

3 F. Capotorti (Special Rapporteur), Study on the Rights of Persons Belonging to Ethnic, Religious and Linguistic Minorities, UN Doc. E/CN.4/Sub.2/384/ Rev.1 (1977).

4 Marc Weller, Escaping the Self-Determination Trap, Leiden, The Netherlands: Martinus Nijhoff Publishers, 2008. 
not be denied the right ... to enjoy their own culture, to profess and practice their own religion, or to use their own language."5 The Human Rights Committee issued a general comment in 1994 regarding Article 27, in which the Committee concluded that states have a positive obligation to protect minority rights and that " $[\mathrm{t}]$ he protection of these rights is directed towards ensuring the survival and continued development of the cultural, religious and social identity of the minorities concerned." 6 In addition, minority rights are protected in the so-called Copenhagen Document, which is an instrument prepared by the Conference on Security and Cooperation in Europe (now the Organization on Security and Cooperation in Europe) at a 1990 meeting in Copenhagen. The Copenhagen Document provides that "[p]ersons belonging to national minorities have the right freely to express, preserve and develop their ethnic, cultural, linguistic or religious identity and to maintain and develop their culture in all its aspects, free of any attempts at assimilation against their will."7 Finally, minority rights are also protected in the Framework Convention for the Protection of National Minorities, a multilateral treaty resulting from the various political commitments of states signatory to the Copenhagen Document. The Framework Convention guarantees to ethnic minorities the right to equal treatment before the law, as well as rights to use their language and to develop a culture, ethnic identity, religion, traditions, and cultural heritage. ${ }^{8}$

Another distinction between minorities and peoples is that minorities may not have a specific territorially linked autonomy claim. Peoples are typically viewed as "whole peoples" or an entire group within a specific nation. ${ }^{9}$ Territorial self-determination and self-government presuppose that all individuals residing within a specific territory have input in making governing decisions. Minorities, on the other hand, may simply constitute territorially dispersed pockets or smaller subgroups of a whole people. Minorities may not be territorial and may not represent a "whole people" within a larger nation; thus, the right to selfdetermination does not attach to minorities.

\footnotetext{
5 International Covenant on Civil and Political Rights art. 27, December 16, 1966.

6 Human Rights Committee, General Comment 23, UN Doc. A/49/50 (Vol. I), at 108 (1994).

7 Copenhagen Conference on the Human Dimension of the CSCE, 29 ILM 1305, II 32 (1990).

8 Framework Convention for the Protection of National Minorities arts 4, 5, 10, 34 ILM 351 (1995).

9 Castellino, supra note 1 , at 33.
} 
To illustrate this point, one might focus on the classification of indigenous groups. It is unclear whether all indigenous groups constitute peoples entitled to self-determination, or whether some indigenous groups may simply be viewed as minority groups. While it may be true that in many cases the presence of an indigenous group within the mother state's territory predates the creation of the mother state itself, and while many indigenous groups may self-identify as unique and separate entities, it is also true that many indigenous groups are dispersed into small communities of a few hundred people and may not have a particularly well-defined territorial claim, as is necessary for the purposes of meaningful self-determination. Some indigenous groups may be too small and uncertain about their own subjective claim to self-government. Such may be the case with the James Bay Crees in Canada — an indigenous or First Nation group under Canadian law, entitled to minority rights but not necessarily entitled to the right of self-determination. ${ }^{10}$ In other words, some indigenous groups may qualify as minorities but not as peoples. In addition, some groups may be populations attached to a particular territorial unit, dispossessed of a valid self-determination claim. For example, countries such as Spain and the United Kingdom may perceive the population of Gibraltar as a group inhabiting particular territory, without attaching self-determination claims to the inhabitants of Gibraltar. In sum, the distinction between peoples and minorities is crucial in international law, as it limits self-determination claims to the former while bestowing nonpolitical protections on the latter. As one commentator has argued, were nonpeoples also entitled to self-determination, "there would be no limit to fragmentation, and peace, security and economic well-being for all would become ever more difficult to achieve."11

In practice, the distinction between peoples and minorities may be extremely difficult to draw. Do indigenous groups qualify as peoples, or

10 The James Bay Crees actually asserted a claim to self-determination, in a brief which they submitted to the Canadian Supreme Court during the Court's consideration of Quebec's proposed secession. They argued that the Crees who lived in Quebec did not identify as a Quebecois "people" and did not wish to secede with Quebec. The Crees also said they would claim the right to secede, "in conformance with international law, should the Cree people and Cree territory be forcibly included in a sovereign Quebec, in violation of their fundamental rights." See Jeffrey L. Dunoff, Steven R. Ratner, and David Wippman, International Law: Norms, Actors, Process, New York, USA: Wolters Kluwer, 2015 [hereinafter Dunoff et al.], on the Crees' case and rejection of a proposed secession with Quebec).

11 Weller, supra note 4 , at 21. 
should one view those as minorities? If one considers Palestinians, Tibetans, and Kurds as peoples, should the same status attach to the Basques, Kashmiris, Chechens, and Tamils? Do the citizens of NagornoKarabakh constitute a "people"? If one conceives of a people as a "whole people" or an entirety of a nation, one may have serious questions about whether the inhabitants of Nagorno-Karabakh do constitute a people. It may be that they are simply Armenian, or Azeri, or a mixture of the two. Assuming that the citizens of Nagorno-Karabakh are a people, what kind of a right to self-determination may they have?

\section{THE HISTORY OF SELF-DETERMINATION}

Self-determination refers to a people's right to choose its political, economic, and social status. It may not necessarily conflict with territorial integrity and state sovereignty because self-determination does not always entail a territorial separation of the people seeking selfdetermination from the mother state of that people. In addition, even in cases where self-determination leads to remedial secession and the creation of a new independent state, self-determination applies before independence, whereas territorial integrity typically applies postindependence. ${ }^{12}$ This section will explore the history behind the principle of self-determination, as well as its various iterations in the postdecolonization era.

The right to self-determination was initially expressed in the American and French revolutions at the end of the eighteenth century, and was considered as a principle which would guarantee democratic consent within an emerging state entity. ${ }^{13}$ Self-determination was subsequently used as the driving ideology behind Latin American decolonization, when former Spanish and Portuguese colonies sought to establish independent states. ${ }^{14}$ Thus, through self-determination, independence was gained for colonially defined territorial units (the same approach would later be used in Africa). After World War I, US President Woodrow Wilson applied the concept of self-determination to minorities, offering them the choice of political belonging through plebiscites. In a February 11, 1918

12 Anne Peters, The Principle of Uti Possidetis Juris: How Relevant Is It for Issues of Secession? in Walter et al., supra note 1, at 126.

13 Thomas M. Franck, The Emerging Right to Democratic Governance, 92 American Journal of International Law 46-91 (1998).

14 Alejandro Alvarez, Latin America and International Law, 3 American Journal of International Law 269, 271 (1909). 
speech to the United States Congress, Wilson famously stated that "self-determination is not a mere phrase; it is an imperative principle of action which statesmen will henceforth ignore at their peril."15 Wilson's ideas were translated somewhat directly onto the dissolution of the Austro-Hungarian and Ottoman Empires in the wake of World War I, resulting in the creation of multiple smaller states (Austria, Hungary, Turkey, Czechoslovakia, Yugoslavia, Finland, Estonia, Latvia, Lithuania, and Poland). During the same period, Lenin relied on self-determination in order to express the idea of peoples expressing their political will in order to rid themselves of bourgeois oppression. ${ }^{16}$ During World War II, self-determination was used by the Nazi regime to justify the reunification of German nations. ${ }^{17}$ In the pre-United Nations Charter era, however, self-determination was more of a political ideology rather than a legal norm. The Covenant of the League of Nations did not mention selfdetermination, and no international treaty espoused self-determination prior to the United Nations Charter itself.

In the United Nations era, self-determination became one of the main vehicles of decolonization. Article 1 of the United Nations Charter states that one of the main purposes of the United Nations is "[ $\mathrm{t}] \mathrm{o}$ develop friendly relations among nations based on respect for the principle of equal rights and self-determination of peoples, and to take other appropriate measures to strengthen universal peace."18 Self-determination continued to transform from a political ideology into a legal norm through the ICCPR, adopted in 1966, as well as through several General Assembly resolutions. Article 1 of the ICCPR provides that "[a]1l peoples have the right of self-determination. By virtue of that right they freely determine their political status and freely pursue their economic, social and cultural development." 19 The 1960 Declaration on the Granting of Independence to Colonial Countries and Peoples provides in Article 2 that "[a]ll peoples have the right to self-determination; by virtue of that right they freely determine their political status and freely pursue their

1556 Cong. Rec. at 8671 (February 11, 1918).

16 Anthony Whelan, Wilsonian Self-Determination and the Versailles Settlement, 43 International and Comparative Law Quarterly 99 (1994).

17 Srdjan Cvijic, Self-Determination as a Challenge to the Legitimacy of Humanitarian Intervention: The Case of Kosovo, 8 German Law Journal 57-80 (2007).

18 UN Charter art. 1.

19 International Covenant on Civil and Political Rights art. 1, December 16, 1966, 999 UNTS 171. 
economic, social, and cultural development."20 In 1970, the so-called Friendly Relations Declaration attempted to enshrine the legal norm of self-determination within the United Nations system by declaring that states have a duty to refrain from forcible actions which would deprive peoples from their right to self-determination, and that colonized peoples have the right to self-determination under the United Nations Charter. ${ }^{21}$

One of the most relevant questions in modern-day international law regarding the right to self-determination is whether the right extends beyond the decolonization context, and if so, what its contours are.

It is disputed in international law whether the right to selfdetermination applies to cases which do not involve decolonization. It may be argued that the United Nations Charter, the ICCPR, and the two General Assembly resolutions specifically refer to the decolonization context and would not be relevant to today's secessionist conflicts. Specifically relevant here is the 1970 Friendly Relations Declaration, which posits the right to self-determination within the decolonization paradigm and bestows it on peoples whose government does not represent their interests:

Nothing in the foregoing paragraphs shall be construed as authorizing or encouraging any action which would dismember or impair, totally or in part, the territorial integrity or political unity of sovereign and independent States conducting themselves in compliance with the principle of equal rights and self-determination of peoples as described above and thus possessed of a government representing the whole people belonging to the territory without distinction as to race, creed or colour. ${ }^{22}$

Many have interpreted the Friendly Relations Declaration to only apply to those peoples whose governments do not act in compliance with principles of "equal rights" and "self-determination of peoples." Scholars have based this argument upon a careful analysis of the Declaration's overall textual provisions, which mention the term "self-determination" a total of eight times, with the first seven mentions occurring either as a

20 Declaration on the Granting of Independence to Colonial Countries and Peoples, GA Res. 1514 (1960).

21 Declaration on Principles of International Law Concerning Friendly Relations and Co-operation among States in Accordance with the Charter of the United Nations, GA Res. 2625 (1970) [hereinafter Friendly Relations Declaration].

22 Ibid. 
general reference or in the context of decolonization. ${ }^{23}$ In addition, scholars have arrived at this conclusion based on an examination of the Declaration's negotiating record, which reflects numerous states' concerns about the possible negative impact that a broad right to selfdetermination would have on existing state boundaries.24 Moreover, scholars have argued that state practice at the time that the Declaration was adopted clearly indicates state support for self-determination in the decolonization context only. ${ }^{25}$ Finally, scholars have pointed out that even if the Declaration were read to confer a broad right of self-determination, this would not imply that such a right would automatically become a part of international law. Thus, according to prominent scholars, international law did not contain, in 1970, a customary norm authorizing selfdetermination of noncolonial peoples, and even today it may be argued that states show extreme reluctance to recognize self-determination as a norm of law outside of the decolonization context. ${ }^{26}$

The right to self-determination has nonetheless been invoked postdecolonization. Some scholars have argued that international law has evolved to embrace the right to self-determination outside of the decolonization context. This argument is based in part on an overall assessment of the Friendly Relations Declaration, read in context with the International Covenants on Civil and Political Rights and on Economic, Social and Cultural Rights - which both bestow on "all peoples" a right to self-determination-as well as with subsequent United Nations declarations in the 1990s affirming this right for linguistic, national, or cultural

23 See, e.g., Milena Sterio, The Right to Self-Determination under International Law: "Selfistans," Secession and the Rule of the Great Powers, Abingdon, UK: Routledge, 2013.

24 Report of the Special Committee on Principles of International Law Concerning Friendly Relations and Co-operation among States, UN GA Res. 25th Sess., Supp. No. 18, at 99, 98, UN Doc. A/8018 (1970).

25 See D.L. Horowitz, A Right to Secede? in Secession and SelfDetermination (Stephen Macedo and Allen Buchanan eds), New York, USA: New York University Press, 2003, at 60 [hereinafter Macedo and Buchanan].

26 See, e.g., Ian Brownlie, Principles of Public International Law, Oxford, UK: Oxford University Press, 2008 at 601-2; Peter Malanczuk, Akehurst's Modern Introduction to International Law, New York, USA: Routledge, 1997, at 334, 339-40; James Crawford, Report: State Practice and International Law in Relation to Secession, February 19, 1997, https://is.muni.cz/el/1422/jaro 2006/MP803Z/um/1393966/INTERNATIONAL_LAW_AND_UNILATERAL_ SECESSION.pdf. 
groups. ${ }^{27}$ As one scholar has noted, United Nations declarations addressing self-determination rights have not clearly differentiated between colonized and noncolonized peoples:

United Nations Declarations that deal with the issue of self-determination on the surface do not make a distinction based on the location of a territory. In general, they state that "all peoples" have the right to self-determination. Neither the U.N.'s International Covenant on Economic, Social and Cultural Rights, nor the Helsinki Final Act give any special status to former colonies ... The Vienna Declaration does not restrict the right of self-determination to former colonies, but merely states that colonial domination should be taken into account in determining whether a people have a right to self-determination. ${ }^{28}$

It may also be possible to argue that the United Nations declarations on self-determination treat noncolonized oppressed peoples similarly to colonized peoples, because the former live within mother states which treat them poorly and exhibit characteristics of pseudocolonies. "If the government is not representative, the oppressed group may be treated as if they were under colonial domination and will have the right to self-determination. In essence, they will be considered a pseudocolony." 29 In addition, "[i]f they are not under colonial domination the people must show that they are oppressed to be considered a pseudocolony and have the right to unilaterally claim independence." 30

Moreover, scholars in the late twentieth century expressed the idea that all peoples should have a right to self-government through meaningful choice and democratic processes. This idea applies both in the decolonization and the nondecolonization paradigms:

International law's deepening devotion to democracy remains what it has long been - a commitment above all to full participatory rights within established states. Emerging norms recognizing a right to self-government lend support to separatist claims principally when those same norms have already been profoundly, irrevocably breached. ${ }^{31}$

27 See Sterio, supra note 23, at 12-13.

28 Roya M. Hanna, Right to Self-Determination in In Re Secession of Quebec, 23 Maryland Journal of International Law 213, 238 (1999).

29 Ibid., at 239.

30 Ibid.

31 Diane Orentlicher, International Responses to Separatist Claims: Are Democratic Principles Relevant? in Macedo and Buchanan, supra note 25, at 21. 
In addition to the scholarly argument about the evolving right of self-determination for all peoples, state practice beginning in the late twentieth century reflects a willingness on behalf of many states to entertain the possibility of democratic principles in examining separatist and self-determination claims. In 1994, the United Nations Security Council authorized a military intervention in Haiti, in order to restore "the legitimately elected President."32 Moreover, states have supported plebiscites across the globe, in order to assess the will of various peoples to remain, or not remain, within a larger mother state. Such plebiscites have occurred in East Timor, Quebec, and Scotland and have enabled peoples to have a voice in choosing their future political fate. ${ }^{33}$ Separatist groups have also relied on the right to self-determination, starting in the late twentieth century, in order to provide a legal basis to their claims. The Quebecois citizens of Canada claimed that they were entitled to self-determination in the 1990s, and so did Serbs living in the newly emerging state of Bosnia and Herzegovina during the same period. ${ }^{34}$ More recently, Kosovar Albanians have claimed the right to selfdetermination from Serbia, and so have South Ossetians and Abkhazians with respect to Georgia. ${ }^{35}$ The International Court of Justice somewhat infamously failed to pronounce itself on the issue of self-determination in the context of nondecolonization in its Kosovo opinion, where it held that the Kosovar declaration of independence was lawful under international law, without declaring whether the Kosovar Albanians had the right to self-determination. ${ }^{36}$ Some scholars have attempted to separate legitimate self-determination claims from illegitimate ones by arguing that the right to self-determination attaches only to peoples which lay a territorial claim to a clearly predefined territorial unit; ${ }^{37}$ in practice,

32 SC Res. 940 (1994).

33 Sterio, supra note 23, at 13; The Guardian, Scottish Independence Referendum: Scotland Votes No-As It Happened (September 19, 2014), www. theguardian.com/politics/scottish-independence-blog/live/2014/sep/18/scottishreferendum-results-live-coverage-of-the-independence-vote.

34 Sterio, supra note 23, at 13.

35 See Chapter 5 for a discussion of Georgia and Chapter 7 for a discussion of Kosovo.

36 Accordance with International Law of the Unilateral Declaration of Independence in Respect of Kosovo (Advisory Opinion) 2010 ICJ 404 (July 22) [hereinafter Kosovo Opinion].

37 Stefan Oeter, The Role of Recognition and Non-Recognition with Regard to Secession, in Walter et al., supra note 1, at 54 ("There has never been any serious international support for a claim of self-determination raised by a simple 'ethnic group' having no firm territorial basis in a pre-existing political entity"). 
however, it is difficult to accurately assess the legitimacy of competing territorial claims.

In sum, it is unclear in international law whether the right to self-determination exists outside of the decolonization paradigm, and even if the right does exist, it is unclear what its parameters may be. The following section will discuss the contours of the right to selfdetermination, by focusing on its two diametrically opposed forms: the right to internal self-determination and the right to external selfdetermination.

\section{INTERNAL AND EXTERNAL SELF-DETERMINATION}

It is unclear what the contours of the right to self-determination may be outside of the decolonization paradigm. Self-determination of peoples can be achieved in various ways: through autonomy, self-government, free association, or, in the most extreme cases, separation from the mother state and the formation of a new state. Self-determination exists on two distinct levels: through internal means of expressing autonomy, or through external means leading toward secession. ${ }^{38}$ Many peoples have been able to exercise their right to internal self-determination within a larger mother state. Such has been the case for the Quebecois in Canada, the Scots in the United Kingdom, the Catalans in Spain; in addition, various other minority groups with statuses falling short of peoplehood have had internal rights recognized within larger federal states, such as in Brazil, Australia, the former Yugoslavia, etc. ${ }^{39}$ The right to internal self-determination, because of its less intrusive nature and its respect for the principle of territorial integrity of existing states, is thus less controversial and can be exercised meaningfully within most contexts. The following section will briefly describe the most prevalent modes of internal self-determination, which include autonomy, protectorates, trusteeships, and free association.

Autonomy can come about through provincial self-government, but it is also possible through the free exercise of political, social, educational, linguistic, and cultural rights by a people living in a larger mother state in a specific geographic area. In addition, autonomy can take the form of

38 Sterio, supra note 23, at 18-19.

39 Ibid., at 19. 
free association, or of a trusteeship or a protectorate. ${ }^{40}$ Examples of peoples exercising a meaningful form of autonomy through which their self-determination rights have been implemented include the Aaland Islands, the Quebecois within Canada, the Catalans within Spain, and the Scots within the United Kingdom. ${ }^{41}$ While some of these peoples may debate the extent to which their right to internal self-determination has truly been respected by the mother state, and while some may harbor secessionist ideals, their attempts at self-determination have, for the most part, been characterized by the international community as successful, foreclosing the necessity of discussing external self-determination. ${ }^{42}$ The Åaland Islands case, which will be discussed presently, exemplifies a successful instance of cultural autonomy for a people within a larger mother state; the Quebec case stands for a positive example of political autonomy; the Catalans and the Scots have been granted the opportunity to vote via referendums as to their preferences regarding remaining within their respective mother states, which may be regarded in and of itself as a meaningful implementation of the (internal) self-determination principle. ${ }^{43}$

A protectorate is a dependent territory which exercises local autonomy and some independence while remaining a territorial unit of a greater sovereign state. In other words, a protectorate is an autonomous part of a sovereign state, unlike an associated state, which is independent from a larger state but has voluntarily ceded parts of its sovereignty to the larger state. ${ }^{44}$ A protectorate is in theory different from a colony, because a protectorate has local rulers which it has chosen freely. Examples of protectorates include Guam, Mariana Islands, Puerto Rico, and the US Virgin Islands, all of which remain dependent territories of the United States. ${ }^{45}$ Before declaring independence in 2008, Kosovo had been a United Nations Protectorate since 1999, and its status today remains disputed. ${ }^{46}$

40 For a discussion of autonomy and self-determination, see Hurst Hannum, Autonomy, Sovereignty, and Self-Determination, Philadelphia, USA: University of Pennsylvania Press.

41 See Chapter 6 for a discussion of Scotland, Quebec, and Catalonia.

42 Ibid.

43 Ibid.

44 For a discussion of protectors as dependent states, see James Crawford, The Creation of States in International Law, Oxford, UK: Clarendon Press, 2006, 394-418.

45 Ibid.

46 For a discussion of Kosovo, see Chapter 7. 
"Trusteeship" was a term invented by the United Nations after World War II; one of the United Nations' principal organs was the United Nations Trusteeship Council, set up to administer trust territories. A trust territory was a territory administered in the best interest of its people and for the sake of international peace and security. ${ }^{47}$ In reality, trust territories were former colonies working their way toward independence; the last trust territory to gain independence was Palau in 1994, and the United Nations Trusteeship Council has since ceased to exist. ${ }^{48} \mathrm{~A}$ trusteeship, similar to a protectorate, could be viewed as a meaningful form of internal self-determination if the trusteeship is distinct from colonialism and if it is based on the free will of the people whose territory is subject to the trusteeship agreement. The difference between a protectorate and a trust territory is that the former may still to this day be a dependent unit of a larger mother state, exercising internal selfdetermination through a specific protectorate arrangement, while all trust territories have by now gained independence. The two are similar if one assumes free will-that in both instances of protectorates and trust territories, it is the people in those regions who determine their political fate and choose whether they wish to remain associated with the larger mother state.

Free association as an expression of self-determination was affirmed as a vehicle of decolonization. General Assembly Resolution 154 offers colonized entities free association as one of three decolonization choices. ${ }^{49}$ In a typical association relationship, an associated state is the minor, and typically territorially smaller, partner in a formal, free relationship between itself and what is usually a larger and more powerful nation. ${ }^{50}$ Associated states may have varying degrees of statehood and may or may not be United Nations members. Free association

47 See United Nations, Trusteeship Council, available at www.un.org/en/ sections/about-un/trusteeship-council/index.html ("In setting up an International Trusteeship System, the Charter established the Trusteeship Council as one of the main organs of the United Nations and assigned to it the task of supervising the administration of Trust Territories placed under the Trusteeship System. The main goals of the System were to promote the advancement of the inhabitants of Trust Territories and their progressive development towards self-government or independence").

48 For a discussion of Palau and its struggle for self-determination, see John Hinck, The Republic of Palau and the United States: Self-Determination Becomes the Price of Free Association, 79 California Law Review 915 (1990).

49 GA Res. 1541.

50 See Zbigniew Dumienski, Microstates as Modern Protected States: Towards a New Definition of Micro-Statehood, Occasional Paper, Centre for 
can be considered a meaningful form of internal self-determination for the associated state, as long as the association relationship is based on free will and consent by the associated state and its people. Free association is a typically common form of political self-expression for microstates, which may not have the territorial and economic capacity to exist completely independently. ${ }^{51}$ Examples of free association today include the Cook Islands and Niue, which are each associated with New Zealand, as well as Palau, the Marshall Islands, and the Federated States of Micronesia, which are each associated with the United States. ${ }^{52}$ Niue and the Cook Islands are not United Nations members, while the other three associated states are; the details of each association agreement vary but in general, the larger state (New Zealand or the United States) promises to ensure some protection for the associated state vis-à-vis such matters as defense and foreign affairs. ${ }^{53}$ Other examples of loose association, whereby a state cedes some specific aspects of sovereignty to a typically larger state, involve five European microstates and three Pacific Island nations. The European microstates include Andorra, which has delegated national defense to Spain and France; San Marino and Monaco, which have delegated defense to Italy and France; Vatican City, whose defense is ensured by Italy and Switzerland; and Lichtenstein, whose diplomatic relations are conducted by Switzerland. ${ }^{54}$ The Pacific

Small State Studies (2014), available at http://ams.hi.is/wp-content/uploads/2014/ 04/Microstates_OccasionalPaper.pdf.

51 Microstates are modern protected states, that is, sovereign states that have been able to unilaterally depute certain attributes of sovereignty to larger powers in exchange for benign protection of their political and economic viability against their geographic or demographic constraints. Ibid.

52 See Central Intelligence Agency, The World Factbook, www.cia.gov/library/ publications/the-world-factbook/geos/cw.html (discussing free associated status of the Cook Islands); Central Intelligence Agency, The World Factbook, www.cia.gov/library/publications/the-world-factbook/geos/ne.html (discussing free associated status of Niue); Central Intelligence Agency, The World Factbook, www.cia.gov/library/publications/the-world-factbook/geos/ps.html (discussing the free associated status of Palau); Central Intelligence Agency, The World Factbook, www.cia.gov/library/publications/the-world-factbook/geos/rm.html (discussing the free associated status of the Marshall Islands); Central Intelligence Agency, The World Factbook, www.cia.gov/library/publications/the-world-factbook/geos/ fm.html (discussing the free associated status of Micronesia).

53 See, e.g., Dunoff et al., supra note 10, at 110.

54 Central Intelligence Agency, The World Factbook, www.cia.gov/library/ publications/the-world-factbook/geos/an.html (discussing the status of Andorra); Central Intelligence Agency, The World Factbook, www.cia.gov/library/ publications/the-world-factbook/geos/sm.html (discussing the status of San 
Island nations include Kiribati and Samoa, whose national defenses are provided by Australia and New Zealand respectively, as well as Nauru, which has delegated its national defense to Australia. ${ }^{55}$ Free associations are examples of internal self-determination because they illustrate situations where peoples, through an expression of their own free will, choose to subject themselves to the sovereignty of another larger state. ${ }^{56}$ Free associations are different from other forms of internal selfdetermination, such as autonomy, a protectorate or a trusteeship, because unlike in the latter cases, an associated state is legally independent and sovereign from the mother state. In this sense, free associations may represent a form of self-determination between internal and external self-determination, as the associated state has achieved legal independence from a larger mother state but has voluntarily ceded parts of its independence to the same mother state, typically due to its small size and inability to assure all types of sovereign protection to its citizens. The most relevant feature of the free association, which posits it as a mode of self-determination, is the exercise of free will by the associated people. So long as a free association is agreed to and implemented consistently with the wishes of the associated people, its specific labeling as a mode of internal or external self-determination becomes irrelevant. Free associations may be more consistent with internal self-determination because they imply consent by both the associated people and the mother state; in cases of true external self-determination, which will be discussed below,

Marino); Central Intelligence Agency, The World Factbook, www.cia.gov/library/ publications/the-world-factbook/geos/mn.html (discussing the status of Monaco); Central Intelligence Agency, The World Factbook, www.cia.gov/library/ publications/the-world-factbook/geos/vt.html (discussing the status of Vatican City); Central Intelligence Agency, The World Factbook, www.cia.gov/ library/publications/the-world-factbook/geos/ls.html (discussing the status of Lichtenstein).

55 Central Intelligence Agency, The World Factbook, www.cia.gov/library/ publications/the-world-factbook/geos/kr.html (discussing the status of Kiribati); Central Intelligence Agency, The World Factbook, www.cia.gov/library/ publications/the-world-factbook/geos/ws.html (discussing the status of Samoa); Central Intelligence Agency, The World Factbook, www.cia.gov/library/ publications/the-world-factbook/geos/nr.html (discussing the status of Nauru).

56 For a discussion of freely associated states and self-determination, see Hannum, supra note 40, at 370. 
the mother state is typically opposed to the quest for separation of the people seeking self-determination. ${ }^{57}$

The right to external self-determination, which is exercised through a people's separation from the mother state, is more difficult to assess legally, considering the competing principles of territorial integrity and existing state sovereignty. States have been reluctant to recognize the existence of the right to external self-determination outside of the context of decolonization. No international treaties address the principle of self-determination directly, and the international documents discussed above, such as the Friendly Relations Declaration, do not shed light on how one is supposed to distinguish between internal and external self-determination and whether the latter is ever available to noncolonial peoples. ${ }^{58}$ Most international law scholars would agree that in light of this situation, the right to external self-determination accrues only in the most extreme instances where a people's right to internal selfdetermination has not been respected by the mother state. ${ }^{59}$ National and international courts have addressed the issue of self-determination a handful of times. The most relevant cases on the distinction between internal and external self-determination include the Aaland Islands case and the Quebec case. In addition, the Badinter Commission has discussed self-determination issues in the context of the dissolution of the former Yugoslavia. The International Court of Justice has also addressed these, albeit tangentially, in its Kosovo opinion. ${ }^{60}$

57 The above discussion on various modes of internal self-determination does not assume that each of the cases cited represents a perfect illustration of the implementation of self-determination principles; in fact, in many instances of free association or protectorates, the terms of the association/protectorate are imposed on the weaker entity or microstate and dictated by the larger state. This chapter discusses these modes of internal self-determination on a theoretical level, and does not cast judgment on any individual case.

58 See Christian Walter and Antje von Ungern-Sternberg, Self-Determination and Secession in International Law-Perspectives and Trends with Particular Focus on the Commonwealth of Independent States, in Walters et al., supra note 1 , at 2 ("the exact contents of the right [to self-determination] remain a matter of dispute: who is entitled ... Is the right, due to its historical origins, solely applicable in situations of decolonization ... And what exactly does selfdetermination comprise: minority rights, autonomy or, as a matter of last resort, a right to secession ...").

59 See, e.g., Michael P. Scharf, Earned Sovereignty: Judicial Underpinnings, 31 Denver Journal of International Law and Policy, 373 (2003).

60 For a discussion of relevant ICJ case law on self-determination issues, see Chapter 8 . 
The Åaland Islands are a small island nation situated between Finland and Sweden. When Finland gained independence following World War I, the Islands became a part of the new Finnish state. ${ }^{61}$ Allanders claimed that they were ethnically Swedish and sought to separate from Finland in order to join Sweden. This exercise would suggest that Ålanders, as a people, wished to exercise their right to external self-determination to secede from Finland and merge into Sweden. The Åaland Islands case ended up before the Commission of Rapporteurs, operating within the auspices of the League of Nations. The Commission held that the Allanders had rights to various forms of autonomy within Finland, but that the right to separate from Finland would not be triggered unless Finland disrespected the Ålanders' meaningful exercise of autonomy within Finland. ${ }^{62}$ The Commission suggested that secession could be available as a "last resort when the State lacks either the will or the power to enact and apply just and effective guarantees" for minority group rights. ${ }^{63}$ The Commission, without embracing the modern-day terminology of internal versus external self-determination, espoused the view that groups such as Allanders have the right to internal selfdetermination within their existing mother state, and that such groups may accrue the right to external self-determination as a "last resort" only, when the mother state chooses to act in ways which no longer respect the group's rights.

A similar view was expressed decades later by the Supreme Court of Canada, in the Quebec case. ${ }^{64}$ The Quebecois population of Canada had, throughout the second half of the twentieth century, demanded greater rights within Canada. These demands culminated in a 1995 referendum in which the Quebecois were asked to express their view on whether to separate from Canada to form an independent state of Quebec. By an extremely slim margin, the Quebecois voted to remain a part of Canada. Given such uncertain referendum results, the Canadian Parliament requested the Supreme Court to issue an opinion on the legality of the proposed Quebecois secession. The Canadian Supreme Court distinguished between the right to internal self-determination and the right to external self-determination. The Court defined the former as "a people's

61 See League of Nations Official Journal, Special Supp. No. 3, at 5-10 (1920).

62 The Aaland Islands Question: Report Submitted to the Council of the League of Nations by the Commission of Rapporteurs, League of Nations Doc. B7/21/68/106 (1921).

63 Ibid.

64 Reference re: Secession of Quebec, 2 SC Res. 217 (1998). 
pursuit of its political, economic, social and cultural development within the framework of an existing state" and the latter as arising "in only the most extreme cases" and "potentially tak[ing] the form of the assertion of a right to unilateral secession." 65 The Court suggested that when a people's right to self-determination is "being totally frustrated" internally, that people may be entitled to exercise external self-determination through remedial secession. ${ }^{66}$ However, the Court was careful to analyze the right to self-determination within the larger context of territorial integrity of states. The Court held that the exercise of any selfdetermination right "must be sufficiently limited to prevent threats to an existing state's territorial integrity or the stability of relations between sovereign states." 67 In addition, the Court concluded that "the general state of international law with respect to the right of self-determination is that the right operates within the overriding protection granted to the territorial integrity of "parent' states." 68 In other words, the right to self-determination should be exercised internally, while protecting the territorial integrity of the existing mother state, and only in the most extreme circumstances and cases may a people claim the right to external self-determination. The Canadian Supreme Court concluded that the Quebecois people in Canada enjoyed the central Canadian government's full respect of their internal self-determination rights. The Court thus declined to elaborate on circumstances which would lead toward the possibility of external self-determination. The Åaland Islands Commission and the Canadian Supreme Court espoused similar views on the distinction between internal and external self-determination, while using different terminology: "the Canadian Supreme Court, like the Åaland Islands Commission, reaffirmed the supremacy of territoriality and the territorial integrity of existing states over any notions of selfdetermination. The latter may disrupt territoriality only in the most extreme circumstances where a people is oppressed by the mother state." 69

A similar and more relevant view of self-determination, as existing within the bounds of the larger norm of state territorial integrity, was expressed by the Badinter Commission in the context of the dissolution of the former Yugoslavia. The Badinter Commission held that international law "does not spell out all the implications of the right to

\footnotetext{
65 Ibid., at II 126.

66 Ibid., at $\llbracket 135$.

67 Ibid., at I130.

68 Ibid., at II 131.

69 Sterio, supra note 23, at 32.
} 
self-determination" and that the right to self-determination "must not involve changes to existing frontiers at the time of independence."70 The Badinter Commission thus seemed to suggest that international law was unclear on self-determination, and that it did not bestow specific selfdetermination rights on groups outside the context of decolonization. Moreover, the Badinter Commission was clear that the right to selfdetermination in the noncolonial context could only exist within the constraints of territorial integrity of existing states. Thus, the Commission seemed to legitimize internal self-determination only in the noncolonial context.

In the Kosovo case, the International Court of Justice was asked to issue an advisory opinion on the legality of the Kosovar declaration of independence under international law. ${ }^{71}$ The more specific circumstances of the Kosovo case will be analyzed in Chapter 7, but for the purposes of this chapter, it suffices to highlight that the world court refused to discuss the right to self-determination in this opinion or to elaborate on when this right may accrue. Instead, the world court held that the Kosovar declaration of independence itself did not violate any specific international law norms, without deciding whether Kosovar Albanians had a positive entitlement to self-determination, leading toward secession. ${ }^{72}$

In sum, in two of the three cases just discussed-Åaland Islands and Quebec - the right to external self-determination was conditioned on the denial of the right to internal self-determination for the secessionist people. Although the League of Nations experts in the Aaland Islands case did not use the legal terminology of internal versus external self-determination, their reasoning was entirely consistent with this dichotomy. In the Quebec case, the Canadian Supreme Court posited that

70 Conference on Yugoslavia Arbitration, Commission Opinion No. 2, 31 ILM 1497 (1992).

71 Kosovo Opinion, supra note 36.

72 "The Court is not required by the question it has been asked to take a position on whether international law conferred a positive entitlement on Kosovo unilaterally to declare its independence or, a fortiori, on whether international law generally confers an entitlement on entities situated within a State unilaterally to break away from it." Ibid., at II 56. It should be noted, however, that one of the dissenting opinions, by Judge Koroma, expressed a clear view that international law does not confer the right to separate from an existing state on any groups, outside of the decolonization context: "To accept otherwise, to allow any ethnic, linguistic or religious group to declare independence and break away from the territory of the State of which it forms part, outside the context of decolonization, creates a very dangerous precedent." Dissenting Opinion of Judge Koroma, II 4. 
the Quebecois may accrue the right to external self-determination if they could demonstrate to the court that their autonomy and internal selfdetermination rights were not being fulfilled by the Canadian government. In the Kosovo case, the International Court of Justice never directly addressed issues of self-determination and secession. Each of these cases will be revisited in Chapter 8; as discussed in this chapter, each case demonstrates that external self-determination has been viewed as a measure of last resort that may be available to a people whose internal rights have been disrespected by the mother state.

\section{CONCLUSION}

In light of the above discussion, it may be argued that any secessionist people would have to demonstrate that its rights to internal selfdetermination were being completely frustrated by the mother state in order to claim that its right to external self-determination had been triggered. Because the most difficult legal issue regarding selfdetermination pertains to its most extreme, external form, resulting in the people's secession from the mother state, Chapter 2 will discuss the right to secession under international law. 